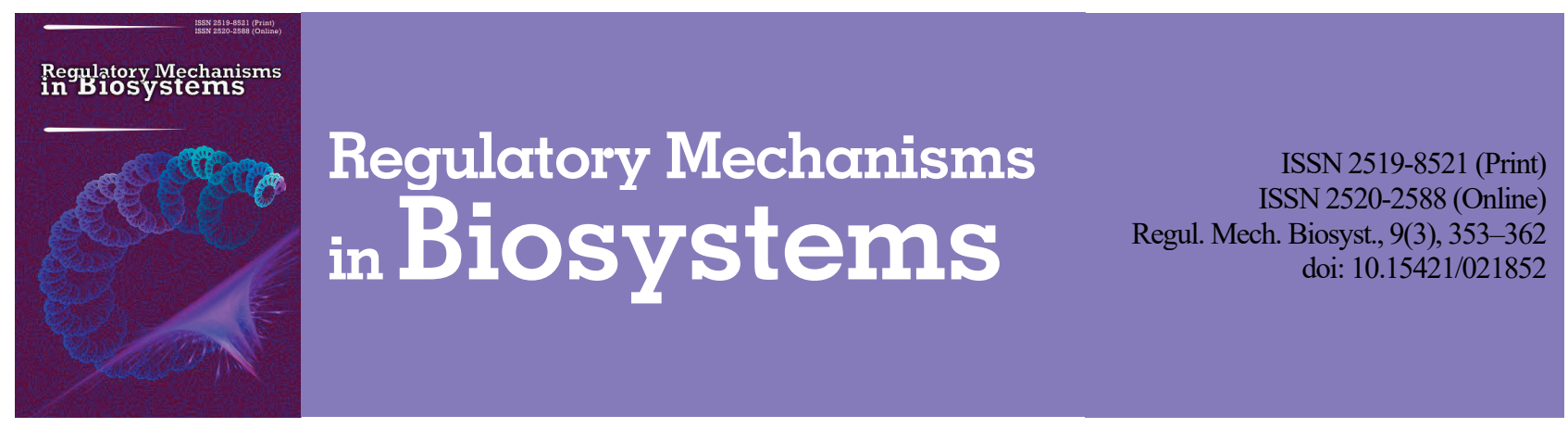

\title{
Pharmacological correction of the hemostasis system for the surgical treatment of bitches with tumours of the mammary gland
}

\author{
D. D. Bely*, M. V. Rublenko**, S. V. Rublenko**, I. D. Yevtushenko***, N. I. Suslova*, V. V. Samoyuluk* \\ *Dnipro State Agrarian and Economic University, Dnipro, Ukraine \\ **Bila Tserkva National Agrarian University, Bila Tserkva, Ukraine \\ ***Kharkiv State Veterinary Academy, Kharkiv, Ukraine
}

Article info

Received 06.07.2018

Received in revised form 14.08.2018

Accepted 17.08.2018

Dipro State Agrarian and

Economic University, Sergiy

Efremov st., 25, Dnipro

49000, Ukraine

Tel.: +38-056-713-51-74.

E-mail:info@dsau.dp.ua

Bila Tserkva National

Agrarian University,

Soborna sq., 8/1, Bila

Tserkva, 09100, Ukraine.

Tel.: +38-045-635-12-88

Kharkiv State Veterinary

Academy, Mala Danylivka, 1,

Derhachivsky Raion, Kharkiv

oblast, 62341, Ukraine.

Tel: +38-057-635-74-23.

E-mail:

zoovet@zoovet.kharkov.ua
Bely, D. D., Rublenko, M. V., Rublenko, S. V., Yevtushenko, I. D., Suslova, N. I., \& Samoyuluk, V. V. (2018). Pharmacological correction of the hemostasis system for the surgical treatment of bitches with tumours of the mammary gland. Regulatory Mechanisms in Biosystems, 9(3), 353-362. doi:10.15421/021852

We carried out the clinical validation of pathogenetically substantiated protocols for the treatment of female dogs with tumour lesions of the mammary gland. The positive effect of corrective therapy was characterized by a decrease in the physiological level of fibrinogen: in benign tumours in 10 days, malignant - in 14 days against the background of its stable high level in control animals with malignant neoplasia. In the postoperative period in experimental animals, the functioning of the internal coagulation unit was restored, as evidenced by the normalization of the activated partial thromboplastin time for benign tumours by days 10-14, malignant by 14 days. In control patients, these changes were detected only for benign neoplasms. Shifts of the external mechanism of blood coagulation in the experimental groups were eliminated in benign neoplasia cases in 10 days, malignant cases in 14 days against the background of severe disorders in this link in control patients throughout the observation period. The positive effect of complex treatment regimens is confirmed by the restoration of total fibrinolytic activity by days 10-14 due to the normalization in the same terms of the plasminogen activator and tissue plasminogen activator by days 3-7. In control animals, the total fibrinolytic activity was consistent with those of clinically healthy animals only for benign neoplasms. The balancing of coagulation and fibrinolytic mechanisms was accompanied by a decrease in the activity of proteolytic inhibitors: $\alpha_{2}$-macroglobulin in experimental groups with benign neoplasia by day 10 , malignant - by days 10-14, and control - respectively, by days 3 and $14 ; \alpha_{1}$-proteinase inhibitor in all groups by day 3 . Concentration of nitric oxide after extirpation of benign tumors already at day 3 of the postoperative period in all groups corresponded to the indexes of clinically healthy dogs, with the removal of malignant tumours - in experimental animals at day 3 , control - at day 14 . The content of malondialdehyde and ceruloplasmin against the background of pharmacological correction was restored by days $10-14$, whereas in control animals - only with benign neoplasms by day 14 . Postoperative pharmacological correction of the hemostasis system can significantly improve the results of treatment in cancer patients.

Keywords: neoplasia; electrocoagulation; dogs; low molecular weight heparins; non-steroidal anti-inflammatory drugs; hemostatic status.

\section{Introduction}

Currently, among the surgical pathologies of small domestic animals, neoplasia is attracting interest from researchers due to the significant increase in registration and inadequate efficacy in treatment of such cases. This situation is related to the increase in the population of small domestic animals, an increase in the unfavourable impact of the environment, the broad use of hormone preparations and high level of metastasis and recurrence. Tumour diseases are one of the commonest causes of the death of dogs and humans (Bonnett et al., 2005).

The difficulty in solving the problem of increasing the effectiveness of therapeutic measures against neoplasia of the mammary gland is caused by the absence of a unified statistical basis, discussion of the pathogenetic mechanisms of this process and low efficiency of early diagnosis, which does not allow one to form the complete chain of formation, development and subsequent behaviour of the tumour source.

A complicated situation in oncopathology, the level of morbidity, the similarity of nonplastic mechanisms of humans and dogs is established (Shafiee et al., 2013; Fürdös et al., 2015) and requires the united efforts of human and veterinary medicine (Ostrander \& Engl, 2012) for coordinating research orientated towards optimizing diagnosis and developing new effective ways of preventing cancer and treating cancer patients (Gardner et al., 2016). Current and previous veterinary records of animals that have been diagnosed with neoplasms of various tissues and organs are few and not systematized. Different inclusion criteria, different methods of collecting and assessing create obstacles for the analysis of available information (Brønden et al., 2007).

At the same time, the most commonly used combination regimen for treating neoplasia, including mammary cancer in dogs, is treatment using a combination of surgical removal and adjuvant and non-adjuvant chemotherapy (Tripp et al., 2011; Leach et al., 2012; Khanna et al., 2015) which, even with the use of modern metronomic protocols, is accompanied by a toxic response of the body (Heading et al., 2011; Marchetti et al., 2012), while the levels of metastasis and relapse remain quite high within 20-50\% (Sarrau et al., 2007).

The research on changes in the blood of animals with cancer only focuses on particular clinical and biochemical blood parameters (Grandi et al., 2016) without analyzing their diagnostic significance in mechanisms of carcinogenesis. Detected relationships between the clinical signs (Sorenmo et al., 2009), pathomorphic (Gundim et al., 2016), cellular, immunohistochemical structures (Beha et al., 2012) and malignancy do not allow us to fully reveal the mechanisms of development and progression of the neoplastic process. At the same time, it has been proved that the main cause of death of animals with tumours is the metastasis 
and thrombosis which accompanies it (Khamis et al., 2012). According to the various statistics, tumour of the mammary gland of dogs is the second commonest among all neoplasms, being recorded on average in $31.9-39.9 \%$ of cases, even reaching $52 \%$ and $56 \%$ (Eierskyte et al., 2011; Abdullah et al., 2014).

Currently, a number of studies focus on the search for an alternative way of influencing neoplasms, which, in combination with surgical intervention, would reduce the possibility of relapse and metastasis. One of the possible directions, considering the role of hemostasis in oncogenesis (Levine et al., 2005; Boccaccio et al., 2006), is influencing the mechanisms of blood coagulation, which would minimise the unfavourable effect of tumour extirpation on hemostasis status and help improve the treatment outcomes.

Thus, the wide distribution of mammary tumours of dogs in the conditions of the tendency to increase in number of cases recorded, discussion of the issues of etiology and pathogenesis, and insufficient effectiveness of therapeutic measures give relevance to and justify the need to study the role of hemostasic status in the mechanisms of tumour development in order to improve diagnostic approaches and optimize antithrombotic therapy for this pathology.

The objective of the study is to assess the effectiveness of pharmacological correction of hemostasic systems, which follows the electrocoagulation of mammary tumours of female dogs.

\section{Material and methods}

The research was conducted at the Department of Surgery and Obstetrics of Farm Animals of the Dnipro State Agrarian and Economic University and the Department of Surgery and Animal Diseases of the Bila Tserkva National Agrarian University. Monitoring of oncological morbidity among dogs was carried out during 2010-2017 on the basis of veterinary hospitals under different forms of ownership in the city of Dnipro, other cities, district centers and villages of Dnipropetrovsk Oblast.

Out of the dogs with mammary tumours, two experimental and one control groups were formed, which included 7-10 year old females with single tumours of the mammary gland of the 2 nd $\left(\mathrm{T}_{2} \mathrm{~N}_{0} \mathrm{M}_{0}\right)$ and $3 \mathrm{rd}\left(\mathrm{T}_{3} \mathrm{~N}_{0} \mathrm{M}_{0}\right)$ stages: the size of the growths was $5-10 \mathrm{~cm}$ in the absence of metastases in the regional lymph nodes and distant tissues. At the same time, 40 animals were included in each experimental group, 20 of which were diagnosed with benign tumours, and 20 - malignant neoplasias, and in the control -32 patients with benign $(\mathrm{n}=16)$ and malignant $(n=16)$ tumours of the mammary gland.

Removal of mammary growths of all of the patients was performed electrosurgically, using an EC-150 electrocoagulator. Unlike the control animals, dogs from the experimental groups, from the second day were prescribed corrective therapy which included: roncoleukin (subcutaneously, in a dose of $15,000 \mathrm{OD} / \mathrm{kg}, 5$ injections at 24 hours intervals) and trannexes (intravenously, at a dose of $15 \mathrm{mg} / \mathrm{kg}, 2$ times/day for 10 days) that were combined for the patients of the first experimental group with nonsteroidal anti-inflammatory preparations (acelizin - intramuscularly, in a dose of $20 \mathrm{mg} / \mathrm{kg}, 2$ times/day for 10 days), the second experimental group - with low molecular weight heparins (phenotype subcutaneously, in a dose of $1.5 \mathrm{mg}$ (1500 anti-Xa MO)/kg once a day over 10 days).

The efficacy of the treatment protocols was determined by the dynamics of biochemical and hemostac parameters of blood prior to the surgical intervention and in the postoperative period on the 3, 7, 10, 14th days.

The coagulation potential of blood plasma was determined by the content of fibrinogen (Belicer et al., 1997) and its metabolite - soluble fibrin (Vareckaja et al., 1992), during activated partial thromboplastin time (a set of reagents manufactured by the company "Simko LTD ", Lviv). The state of the fibrinolysis system was investigated using the method of fibrin plates according to Astrup \& Millertz (1952), with the definition of total fibrinolytic activity of blood plasma, plasmin activity and tissue plasminogen activator activity, by the lysis area $(\mathrm{mm} 2)$ of the fibrin blood clot.

The inhibitory potential of the blood was determined by the content of $\alpha_{1}$-proteinase inhibitor and $\alpha_{2}$-macroglobulin in the plasma (Veremeenko et al., 1978).
In the blood plasma or serum, we determined the content of the total protein by the biuretic reaction using a set of reagents manufactured by the "Reagent" company, the content of albumin - by the reaction with bromocresol green, the content of ceruloplasmin - using the method of Ravin, malonic dialdehyde (Andreeva, 1988), and nitric oxide (Golikov, 2004).

The statistical analysis of the results was carried out using the Statistica 10 program (StatSoft Inc., USA, 2011). The reliability of the differences between the samples was determined using ANOVA, considered significant at $\mathrm{P}<0.05$.

\section{Results}

Monitoring research included a survey of 10,118 dogs, including 1,063 cancer patients with various clinical and pathomorphological forms of mammary gland neoplasia.

In the comparative analysis of the prevalence of mammary tumours of dogs in conditions of industrial cities, district centers and rural areas of Dnipropetrovsk Oblast (Table 1), it was found that the lowest level of occurrence of mammary tumours was recorded in villages: they were diagnosed in every fifth cancer patient. In district centers which are represented by small towns or urbanized settlements and in the city of Dnipro, neoplastic growths in the mammary gland were detected in every third dog of the total number of animals with tumours. At the same time, the frequency of neoplastic lesions of the mammary gland in ecologically polluted cities (Kamianske, Kryvy Rih, Marhanets, Zhovti Vody) reached $42 \%$. This difference in the latter case occurs due to the unfavourable impact of environmental factors. At the same time, it should be mentioned that the relatively low level of detection of mammary neoplasia in rural areas is conditioned by the low frequency of contacting veterinary hospitals, and in the conditions of the city of Dnipro - the prevalence of sterilization measures, including an intensive programme of sterilization of homeless animals.

\section{Table 1}

Monitoring of tumour lesions of female dogs in Dnipropetrovsk region (\%)

\begin{tabular}{lcccc}
\hline \multicolumn{1}{c}{ Characteristics } & Dnipro & $\begin{array}{c}\text { Environmentally } \\
\text { polluted cities* }\end{array}$ & $\begin{array}{c}\text { District } \\
\text { centers }\end{array}$ & Villages \\
\hline $\begin{array}{l}\text { Tumors, all } \\
\text { Neoplasia of the }\end{array}$ & 100 & 100 & 100 & 100 \\
mammary gland & 29 & 42 & 30 & 20 \\
\hline
\end{tabular}

Note: *-Kamianske, Kryvy Rih, Marhanets, Zhovti Vody.

Comparative morphological analysis of pathological material (Table 2) indicates a significant prevalence of malignant neoplasia over benign neoplasia among dogs in industrial, environmentally polluted cities (the ratio is $2.5: 1$ ). A similar situation, but with a smaller difference, was recorded in the villages $(1.4: 1)$ in the absence of a pronounced difference in the district centers $(1.1: 1)$, while in the city of Dnipro, benign neoplasms $(1: 1.2)$ prevail. Other clinical parameters were similar and independent of the area where the animals lived: the fifth pair of mammary glands was the most often affected (33\% of cases), the fourth pair more rarely $(21 \%)$, and also the third $(19 \%)$ and the second $(18 \%)$. Only $9 \%$ of animals were diagnosed with tumour process in the first pair of mammary glands. At the same time, multiple lesions were recorded for benign neoplasms in $21 \%$ of dogs, malignant - only in $8 \%$.

\section{Table 2}

Prevalence of breast tumours in dogs in different regions of Dnipropetrovsk region (\%)

\begin{tabular}{lcccc}
\hline $\begin{array}{c}\text { Breast } \\
\text { tumours }\end{array}$ & Dnipro & $\begin{array}{c}\text { Environmentally } \\
\text { polluted cities* }\end{array}$ & District centers & Villages \\
\hline Benign & 54 & 29 & 47 & 41 \\
Malignant & 46 & 71 & 53 & 59 \\
Together & 100 & 100 & 100 & 100 \\
\hline
\end{tabular}

Note: *-Kamianske, Kryvy Rih, Marhanets, Zhovti Vody.

Studies on the hemostastic status of animals with tumours allowed us to identify certain patterns that reflect the adverse effect of the tumour 
on the system of coagulation and fibrinolysis and the corresponding protective response of the organism (Table 3 ). In most cases, they are characterized by increased blood coagulation following the inhibition of its lysis, which indicates the development of DIC-syndrome. In particular, we recorded excessive accumulation of fibrinogen, soluble fibrin, shortening of activated partial thromboplastin time, decrease of total fibrinolytic activity following the increase in the level of its inhibitors
( $\alpha_{1}$-inhibitor of proteases and $\alpha_{2}$-macroglubulin) and increased nitrogen oxide content. These changes were manifested more clearly in cases of malignant neoplasm. At the same time, it should be mentioned that there were significant fluctuations in the markers which reflect the extent of imbalance in the processes of blood coagulation and lysis, their different vector orientation, and in some cases - the lack of changes compared to the clinically healthy animals.

Table 3

Hemostatic status of female dogs with tumours of the mammary gland $(x \pm S D)$

\begin{tabular}{|c|c|c|c|}
\hline \multirow{2}{*}{ Indicator } & \multirow{2}{*}{ Clinically healthy $(\mathrm{n}=30)$} & \multicolumn{2}{|c|}{ Tumours } \\
\hline & & benign $(n=35)$ & malignant $(\mathrm{n}=35)$ \\
\hline Fibrinogen, g/l & $2.20 \pm 0.12$ & $2.62 \pm 0.15^{*}$ & $5.09 \pm 0.19 * * * .$. \\
\hline Soluble fibrin, $\mathrm{mg} / 100 \mathrm{ml}$ & 0 & $30.73 \pm 4.17 * * *$ & $49.87 \pm 5.22 * * * . \bullet$ \\
\hline Activated partial thromboplastin time, $\mathrm{s}$ & $46.13 \pm 1.35$ & $46.08 \pm 5.16$ & $69.53 \pm 4.82 * *_{\bullet \bullet}$ \\
\hline Total fibrinolytic activity, $\mathrm{mm}^{2}$ & $607.76 \pm 22.85$ & $482.69 \pm 40.19^{* *}$ & $417.42 \pm 36.24 * *$ \\
\hline Plasma activator, $\mathrm{mm}^{2}$ & $284.42 \pm 11.61$ & $214.86 \pm 21.25^{* *}$ & $241.80 \pm 19.09 * *$ \\
\hline Tissue plasminogen activator, $\mathrm{mm}^{2}$ & $323.34 \pm 25.24$ & $267.83 \pm 23.17^{*}$ & $175.62 \pm 16.95 * * . \bullet$ \\
\hline$\alpha_{1}$ - proteinase inhibitor, $\mu \mathrm{mol} / 1$ & $78.62 \pm 1.93$ & $89.80 \pm 7.53^{*}$ & $105.89 \pm 8.19^{* *} \bullet$ \\
\hline$\alpha_{2}$-macroglobulin, $\mathrm{g} / \mathrm{l}$ & $1.43 \pm 0.05$ & $1.72 \pm 0.21 *$ & $2.25 \pm 0.07 * * * \bullet$ \\
\hline Nitric oxide, $\mu \mathrm{mol} / 1$ & $32.19 \pm 1.82$ & $29.74 \pm 4.03$ & $42.85 \pm 4.89 * * \bullet$ \\
\hline
\end{tabular}

Note: $*-\mathrm{P}<0.05, * *-\mathrm{P}<0.01, * * *-\mathrm{P}<0.001$ compared to clinically healthy dogs; $\bullet-\mathrm{P}<0.05, \bullet-\mathrm{P}<0.01, \cdots-\mathrm{P}<0.001$ with respect to indicators in females with benign tumours.

Regardless of the structure of the neoplastic tissue, the tumour process caused excessive accumulation of fibrinogen. In cases of the malignant course, the fibrinogen level in the blood was over $3.3 \mathrm{~g} / 1$ (1.5 times more than the physiological index) in $93 \%$ of the animals, and with benign tumours of the mammary gland - in $68 \%$ of patients. The absence of changes in this marker was determined for malignant neoplasia of the mammary gland in $6 \%$, for benign tumours - in 3\% of bitches. Thus, the main characteristic of the malignant course is the excessive accumulation of fibrinogen in the blood of $80 \%$ of patients when a significant difference obtained $(\mathrm{P}<0.01)$ compared to the clinically healthy animals and dogs with benign tumours.

In correlation with fibrinogen, the early phase of hypercoagulative process and the degree of expression of inflammation during tumours characterizes the content of soluble fibrin, which in an absolute majority of cases exceeded the parameters of clinically healthy animals. However, the wide range of fluctuations in the concentration of soluble fibrin in the blood should be mentioned: 2.0 to $97.5 \mathrm{mg} / 100 \mathrm{ml}$ in the cases of malignant tumours, 1.3 to $58.1 \mathrm{mg} / 100 \mathrm{ml}$ - with benign tumours. The averages determined allow one to assume a statistically higher level of soluble fibrin in bitches with malignant lesions of the mammary gland $(\mathrm{P}<0.01)$.

The obtained results indicate that with benign growths, no dissolved fibrin was found in the blood of $20 \%$ of the dogs, while with malignant tumours, its content was over the norm in all cases. Thus, the content of soluble fibrin correlates with fibrinogen, indicating the presence of hypercoagulative changes and determining the level of malignancy of the neoplasia process.

The mean values of the activated partial thromboplastin time, which characterizes the internal and general cascade of the blood coagulation system, allows us to estimate the initial stage of coagulation - the formation of thromboplastin indicates its lengthening in the case of malignant neoplasms $(\mathrm{P}<0.01)$ and the absence of clearly manifested changes in benign tumours in the conditions of the statistical difference between the groups depending on the malignancy of the lesion $(\mathrm{P}<$ 0.01). The duration of the activated partial thromboplastin time among all patients significantly differed from the physiological parameters with the fluctuation of parameters in a wide range.

In cases of malignant neoplasia, the prolongation and shortening of this marker were observed in approximately the same number of cases ( $51 \%$ and $49 \%$ respectively), and in cases of benign tumours, a typical feature was the prevalence of the number of animals in which this indicator had a reduced duration ( $71 \%$ vs $29 \%$ ). It was determined that the borders of the fluctuations of this indicator were: $30.7-106.1 \mathrm{~s}$ for malignant neoplasms, 28.7-89.3 $\mathrm{s}$ - for benign tumours.

The results of the study of the state of the fibrinolytic element of the hemostasic system in animals with mammary tumours indicate a decrease in its activity in patients of both groups $(\mathrm{P}<0.01)$ due to plasmin activity $(\mathrm{P}<0.05)$ and tissue plasminogen activator $(\mathrm{P}<0.05)$ following the statistical difference between malignant and benign tumors only in the parameters of tissue plasminogen activator $(\mathrm{P}<0.01)$. Regardless of the morphological structure of the tumours, in the vast majority of cases, the inhibition of the level of total fibrinolytic activity was observed: $88.9 \%$ for benign tumours, $82.9 \%$ - malignant tumours at fluctuations within $50 \%$ from the physiological parameters.

In animals with tumours of the mammary gland, an increase in the proteolytic activity of the blood was recorded. The analysis of the results allowed us to determine a reliable difference between the mean levels of $\alpha_{1}$-proteinase inhibitor and $\alpha_{2}$-macroglobulin in female dogs with benign $(\mathrm{P}<0.05)$ and malignant $(\mathrm{P}<0.01)$ mammary tumours and clinically healthy animals. Moreover, the activity of these inhibitors of proteolysis was statistically higher in the patients with a malignant process $(\mathrm{P}<0.05)$.

The examination of the oxidative system of the dogs with mammary tumours revealed a statistically significant difference in the nitrogen oxide content between the clinically healthy animals and the patients with malignant lesions $(\mathrm{P}<0.01)$. At the same time, in the cases of the benign neoplastic process, the average content of its stable metabolites did not differ significantly from the physiological parameters, although some animals were observed to have a reduction to $23.7 \mu \mathrm{mol} / \mathrm{l}$ and increase to $43.5 \mu \mathrm{mol} / 1$ in nitric oxide concentration.

Thus, the study of the hemostatic status of female dogs with spontaneous tumours of the mammary gland has revealed that during the development of neoplasia, metastasis of tumour cells, a certain dynamic occurs in the ratios of procoagulant, anticoagulant mechanisms and system of fibrinolysis, which determine the prognostically unfavourable background for this pathology.

The need for pharmacological correction in dogs with mammary tumours is conditioned by the following facts:

- insufficient effectiveness of surgical intervention;

- disorders in the coagulation and fibrinolytic links of hemostasis;

- proven significance of hemostasis mechanisms in the pathogenesis of tumour growth and progression;

- absence of normalization of indicators of coagulation and lysis of blood 14 days after removal of neoplasia.

Therefore, subsequent research focused on determining the effectiveness of correction of mechanisms of hemostasis after using EC-150 electrocoagulator for this pathology.

The practical testing of the developed schemes was evaluated, first of all, by the change in the concentration of fibrinogen (Table 4), which reflects the level of disorders in coagulation mechanisms and the intensity of the inflammatory reaction (as an osteophatic protein).

The content of this marker in the blood of dogs after the removal of benign tumours and the corrective therapy, in contrast to the samples of the control animals, during the first 7 days was at the preoperative level. 
From the 10th day, the normalization of the fibrinogen content was recorded in all groups of patients. Thus, the main determined differences are related to the first week after the surgical intervention. They manifested in the fact that in this period of time, the females of the control group had a significantly decreased concentration of fibrinogen in relation to both clinically healthy dogs and to primary parameters $(\mathrm{P}<0.01)$. At the same time, in the animals of the experimental groups this indicator remained significantly higher than the physiological norms, not significantly differing from the level of this marker among the dogs with tumours.

Changes in the concentration of fibrinogen in the patients with extirpation of malignant neoplasia were similar, but with certain peculiarities. In particular, the restoration of its level occurred only in the cases of using the corrective schemes for 14 days after surgery. It should be mentioned that the dynamics of this indicator did not depend on the prescribed correction scheme. The dynamics of the level of accumulation of soluble fibrin in the blood are confirmed by the influence of the proposed protocols of the pharmacological correction of the hemostasis system on the coagulation level.

\section{Table 4}

Dynamics of fibrinogen for pharmacological correction in bitches with tumours of the mammary glands $(\mathrm{g} / \mathrm{l}, \mathrm{x} \pm \mathrm{SD})$

\begin{tabular}{|c|c|c|c|}
\hline \multirow[b]{2}{*}{$\begin{array}{c}\text { Period } \\
\text { of observation, } \\
\text { day }\end{array}$} & \multicolumn{3}{|c|}{ Group } \\
\hline & $\begin{array}{l}\text { control } \\
(\mathrm{n}=32)\end{array}$ & $\begin{array}{l}\text { first experimental } \\
\qquad(\mathrm{n}=40) \\
\text { coagulator } \\
\text { + non-steroidal anti- } \\
\text { inflammatory drugs }\end{array}$ & $\begin{array}{l}\text { second experimental } \\
\qquad(\mathrm{n}=40) \\
\text { coagulator } \\
+ \text { low molecular } \\
\text { weight heparins }\end{array}$ \\
\hline Clinically healthy & & $2.20 \pm 0.12$ & \\
\hline \multicolumn{4}{|c|}{ Benign tumours } \\
\hline Before surgery & & $2.62 \pm 0.15^{*}$ & \\
\hline 3 & $1.28 \pm 0.08 * * *$ & $3.07 \pm 0.44 * \bullet$ & $2.95 \pm 0.41 * \bullet$ \\
\hline 7 & $1.43 \pm 0.16^{*}$ & $2.87 \pm 0.38 * \bullet$ & $2.77 \pm 0.29 * \bullet$ \\
\hline 10 & $2.05 \pm 0.11$ & $2.35 \pm 0.26$ & $2.52 \pm 0.32$ \\
\hline 14 & $2.47 \pm 0.14$ & $2.24 \pm 0.51$ & $2.47 \pm 0.17$ \\
\hline \multicolumn{4}{|c|}{ Malignant neoplasms } \\
\hline Before surgery & & $5.09 \pm 0.19 * *$ & \\
\hline 3 & $1.17 \pm 0.06^{* * *}$ & $3.00 \pm 0.31 *_{\bullet \bullet}$ & $3.09 \pm 0.51 * \bullet$ \\
\hline 7 & $1.31 \pm 0.17 * * *$ & $2.92 \pm 0.42 * \bullet$ & $2.87 \pm 0.38 * \bullet$ \\
\hline 10 & $1.52 \pm 0.14 * *$ & $2.53 \pm 0.29 \bullet \bullet$ & $2.64 \pm 0.42 \bullet$ \\
\hline 14 & $1.89 \pm 0.13^{*}$ & $2.26 \pm 0.33$ & $2.38 \pm 0.46$ \\
\hline
\end{tabular}

Note: see Table 3 .

The analysis of the concentration of soluble fibrin in the blood of patients after the removal of mammary tumours and prescription of preparations for correcting the hemostasis system, regardless of the malignancy of the process was characterized by the following features (Table 5). In all groups, the excess accumulation of the mentioned marker, was conditioned by the presence of neoplasia; after its extirpation, a gradual decrease in its level occurred. However, both in cases of benign and malignant tumours, conducting only surgical intervention was not enough for restoring the parameters of the content of soluble fibrin during 14 days: it exceeded the parameters of clinically healthy dogs by two times.

Combining electrosurgical excision of neoplasms with directed pharmacological therapy allowed us to maximally approximate its concentration to the parameters of clinically healthy animals. At the same time, the dynamics of the level of soluble fibrin in the experimental groups did not differ significantly. Particularly, the prescription of nonsteroidal antiinflammatory preparations and low molecular weight heparins allowed reduction in the content of this marker in cases of benign tumours to $0.3-0.4 \mathrm{mg} / 100 \mathrm{ml}$, and to $0.9-1.0 \mathrm{mg} / 100 \mathrm{ml}$ - in cases of malignant tumours. That is, the patients who were prescribed pharmacological correction of hemostatic status in the postoperative period were observed to have a significantly lower level of soluble fibrin in the blood compared to the control animals, whereas no significant difference occurred between the experimental groups.

Analysing the results obtained (Table 6), we can assess the effectiveness of the developed correction courses for benign neoplasia of the mammary gland: the normalization of the level of soluble fibrin indicates the bringing of blood coagulation and fibrinolysis into balance. Thus, the research conducted has confirmed the effectiveness of the schemes of complex pharmacological correction in dogs with tumour lesions of the mammary gland, which was reflected in the normalization of the concentration of fibrinogen and soluble fibrin in the blood, which are markers of hypercoagulative disorders of the hemostasis system. In this case, it would be logical to assume a mediation (through the mechanisms of blood coagulation and lysis) optimization of the course of healing of surgical wounds, as well as the reduction of the risk of postoperative complications: both local inflammatory purulent, and also possible relapse and metastasis complications.

\section{Table 5}

Influence of pharmacological correction on the content of soluble fibrin in bitches after extirpation of mammary gland neoplasia $(\mathrm{mg} / 100 \mathrm{ml}, \mathrm{x} \pm \mathrm{SD})$

\begin{tabular}{|c|c|c|c|}
\hline \multirow[b]{2}{*}{$\begin{array}{c}\text { Period of } \\
\text { observation, } \\
\text { day }\end{array}$} & \multicolumn{3}{|c|}{ Group } \\
\hline & 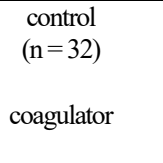 & $\begin{array}{l}\text { first experimental } \\
\qquad(\mathrm{n}=40) \\
\text { coagulator + non- } \\
\text { steroidal anti- } \\
\text { inflammatory drugs }\end{array}$ & $\begin{array}{l}\text { second experimental } \\
\qquad(\mathrm{n}=40) \\
\text { coagulator }+ \text { low } \\
\text { molecular weight } \\
\text { heparins }\end{array}$ \\
\hline Before surgery & & 0 & \\
\hline \multicolumn{4}{|c|}{ Benign tumours } \\
\hline Before surgery & & $30.73 \pm 4.17 * * *$ & \\
\hline 3 & $5.41 \pm 0.39 * * *$ & $2.35 \pm 0.24 * * *$. & $2.81 \pm 0.43^{* * * . .}$ \\
\hline 7 & $4.08 \pm 0.27 * * *$ & $1.98 \pm 0.35^{* * * \bullet}$ & $1.57 \pm 0.36^{* * * . . .}$ \\
\hline 10 & $2.39 \pm 0.16^{* * *}$ & $1.49 \pm 0.22 * * * .$. & $0.81 \pm 0.12^{* * * \ldots . .}$ \\
\hline 14 & $2.12 \pm 0.19 * * *$ & $0.32 \pm 0.21 * .$. & $0.34 \pm 0.25 * \bullet$ \\
\hline \multicolumn{4}{|c|}{ Malignant neoplasms } \\
\hline Before surgery & & $49.87 \pm 5.22 * *$ & \\
\hline 3 & $7.19 \pm 0.52 * * *$ & $4.85 \pm 0.69 * * * . \bullet$ & $3.23 \pm 0.16^{* * * . . .}$ \\
\hline 7 & $6.18 \pm 0.33 * * *$ & $3.42 \pm 0.56 * * *$. & $2.15 \pm 0.67 * * * \ldots$ \\
\hline 10 & $4.59 \pm 0.24 * * *$ & $2.08 \pm 0.31 * * * .$. & $1.64 \pm 0.24 * * * . .$. \\
\hline 14 & $3.01 \pm 0.27 * * *$ & $0.85 \pm 0.32 *_{\bullet \bullet}$ & $0.94 \pm 0.47 *_{*} . \bullet$ \\
\hline
\end{tabular}

Note: see Table 3.

Table 6

Change in activated partial thromboplastin time after extirpation of breast cancer neoplasia in dogs $(\mathrm{s}, \mathrm{x} \pm \mathrm{SD})$

\begin{tabular}{|c|c|c|c|}
\hline \multirow[b]{2}{*}{$\begin{array}{c}\text { Period of } \\
\text { observation, day }\end{array}$} & \multicolumn{3}{|c|}{ Group } \\
\hline & 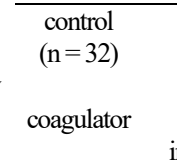 & $\begin{array}{l}\text { first experimental } \\
\qquad(\mathrm{n}=40) \\
\text { coagulator + non- } \\
\text { steroidal anti- } \\
\text { inflammatory drugs }\end{array}$ & $\begin{array}{l}\text { second experimental } \\
\qquad(\mathrm{n}=40) \\
\text { coagulator }+ \text { low } \\
\text { molecular weight } \\
\text { heparins }\end{array}$ \\
\hline Clinically healthy & \multicolumn{3}{|c|}{$46.13 \pm 1.35$} \\
\hline \multicolumn{4}{|c|}{ Benign tumours } \\
\hline Before surgery & \multicolumn{3}{|c|}{$46.08 \pm 5.16$} \\
\hline 3 & $35.24 \pm 1.94 * *$ & $31.67 \pm 1.53^{* * *}$ & $34.54 \pm 5.21 *$ \\
\hline 7 & $33.15 \pm 1.22^{* * *}$ & $36.05 \pm 3.81^{*}$ & $38.27 \pm 4.03 *$ \\
\hline 10 & $37.28 \pm 1.61 * *$ & $40.21 \pm 3.24 *$ & $42.82 \pm 3.45 \bullet$ \\
\hline 14 & $43.99 \pm 2.17$ & $44.53 \pm 3.89$ & $43.41 \pm 4.98$ \\
\hline \multicolumn{4}{|c|}{ Malignant neoplasms } \\
\hline Before surgery & & $69.53 \pm 4.82 * *$ & \\
\hline 3 & $25.25 \pm 1.16^{* * *}$ & $24.13 \pm 2.63^{* * *}$ & $36.50 \pm 2.38 * \bullet$ \\
\hline 7 & $23.05 \pm 0.97 * * *$ & $27.23 \pm 1.98^{* * *}$ & $37.89 \pm 2.47 * \bullet$ \\
\hline 10 & $29.52 \pm 0.96^{* * *}$ & $33.60 \pm 2.85^{* *}$ & $39.67 \pm 3.04 * \bullet$ \\
\hline 14 & $38.74 \pm 0.78 * *$ & $41.27 \pm 3.12$ & $40.05 \pm 3.31$ \\
\hline
\end{tabular}

Note: see Table 3.

The study of the duration of activated partial thromboplastin time in animals which were prescribed postoperative corrective therapy indicates a greater efficacy of the pharmacological course which included low molecular weight heparins, regardless of the structure of the neoplasia.

The dogs after extirpation of benign tumours were observed to experience normalization of the duration of activated partial thromboplastin time in the control and the first experimental groups on the 14th day of the postoperative period, and in the second experimental group - on the 10th day. Indicators of the duration of activated partial thromboplastin time in females after the removal of malignant neoplasia differed significantly between the groups depending on the protocol used for correction. After 14 days, in the animals of the control group the activated 
partial thromboplastin time was accelerated $(\mathrm{P}<0.05)$, and a stabilization of this marker was recorded with the experimental animals, both in the cases of prescription of non-steroidal anti-inflammatory preparations and low molecular weight heparins.

It should be mentioned that during the first 10 days after the surgical intervention in dogs with malignant neoplasms, the parameters of the second experimental group significantly differed from those of the first experimental $(\mathrm{P}<0.05)$ and the control group $(\mathrm{P}<0.01)$. The duration of activated partial thromboplastin time in patients which were prescribed low molecular weight heparins was statistically higher $(\mathrm{P}<0.05)$ compared to animals prescribed nonsteroidal anti-inflammatory preparations. Thus, the postoperative period was characterized by shortened activated partial thromboplastin time in all animals with a subsequent tendency of prolongation. Regarding the normalization of this marker, the best results were obtained when low molecular weight heparins were added to the pharmacological correction course, although the advantage was not significant.

The dynamics of the total fibrinolytic activity of blood after the excision of mammary tumours of dogs the confirms the feasibility of the corrective therapy (Table 7). Reduced intensity of proteolytic mechanisms, even after removal of tumorrs, restores in two weeks only in cases of benign tumours. Prescribing preparations for correcting the hemostasic system allows its activity to be restored. After introducing low molecular weight heparins, these changes were observed on the 10th day in cases of benign neoplasias, and on the 14th day - in cases of malignant tumours; with use of nonsteroidal anti-inflammatory preparations - on the 14th day in both cases.

It should be mentioned that the total fibrinolytic activity in patients of the control group was significantly lower than the corresponding parameters in the experimental groups in cases of benign tumours on the 7th and 10th days of monitoring, and on the 3d, 10th and 14th days in cases of malignant tumours $(\mathrm{P}<0.05)$.

The disorders among different elements of the hemostasis system which were found in the previous studies, particularly disorders in the levels of proteinase inhibitors, indicate a high risk of hemocoagulation complications, therefore prescribing postoperative corrections is necessary. Therefore, we studied the dynamics of their changes in the case of using low molecular weight heparins and nonsteroidal anti-inflammatory agents after usage of EC-150 electrocoagulator.

\section{Table 7}

Influence of pharmacological correction

on total fibrinolytic activity of blood in oncopatients $\left(\mathrm{mm}^{2}, \mathrm{x} \pm \mathrm{SD}\right)$

\begin{tabular}{cccc}
\hline & \multicolumn{4}{c}{ Group } \\
\cline { 2 - 4 } $\begin{array}{c}\text { Period of } \\
\text { observation, day }\end{array}$ & $\begin{array}{c}\text { control } \\
(\mathrm{n}=32)\end{array}$ & $\begin{array}{c}\text { first experimental } \\
(\mathrm{n}=40) \\
\text { coagulator + non- } \\
\text { steroidal anti- } \\
\text { inflammatory drugs }\end{array}$ & $\begin{array}{c}\text { second xeperimental } \\
(\mathrm{n}=40) \\
\text { coagulator }+ \text { low } \\
\text { molecular weight } \\
\text { heparins }\end{array}$ \\
\hline Clinically healthy & \multicolumn{4}{c}{$607.76 \pm 22.85$} \\
\hline \multicolumn{4}{c}{ Benign tumours } \\
\hline Before surgery & $482.69 \pm 40.19^{* *}$ \\
\hline 3 & $409.58 \pm 17.15^{* * *}$ & $458.21 \pm 36.97^{* *}$ & $418.13 \pm 18.29^{* * *}$ \\
7 & $412.72 \pm 19.38^{* * *}$ & $509.16 \pm 27.39^{* * *}$ & $496.32 \pm 37.04^{* * \bullet}$ \\
10 & $484.29 \pm 23.03^{* *}$ & $548.67 \pm 30.52^{* \bullet}$ & $597.45 \pm 23.16 \bullet \bullet$ \\
14 & $590.03 \pm 25.12$ & $614.93 \pm 29.34$ & $609.15 \pm 20.47$ \\
\hline \multicolumn{4}{c}{$417.42 \pm 36.24^{* *}$} \\
\hline Before surgery & Malignant neoplasms \\
\hline 3 & $372.21 \pm 21.15^{* * *}$ & $420.91 \pm 28.67^{* * *}$ & $473.68 \pm 28.94^{* * \bullet}$ \\
7 & $488.34 \pm 16.59^{* *}$ & $529.14 \pm 30.51^{*}$ & $517.62 \pm 23.42^{* *}$ \\
10 & $443.56 \pm 29.25^{* *}$ & $553.48 \pm 21.84^{* \bullet \bullet}$ & $548.96 \pm 24.53^{* \bullet \bullet}$ \\
14 & $491.38 \pm 15.87^{* *}$ & $603.62 \pm 24.63 * \bullet$ & $618.92 \pm 31.05 \bullet \bullet$ \\
\hline
\end{tabular}

Note: see Table 3.

Unlike the patients in the control group, whose treatment measures consisted of extirpating tumours using the electrosurgical technique, the postoperative period in the case of prescribing the corrective therapy, the content of $\alpha_{2}$-macrogluculin did not significantly change during the first seven days (Table 8), exceeding the parameters of the clinically healthy dogs on average by $50-70 \%$. Later, the concentration of this marker decreased to the physiological level. The exceptions were females with malignant tumours, which were prescribed low molecular weight heparins (these changes were observed after ten days).

\section{Table 8}

Influence of different courses of treatment

of mammary tumours on the level of $\alpha_{2}$-macroglobulin $(g / l, x \pm S D)$

\begin{tabular}{|c|c|c|c|}
\hline \multirow[b]{2}{*}{$\begin{array}{c}\text { Period of } \\
\text { observation, day }\end{array}$} & \multicolumn{3}{|c|}{ Group } \\
\hline & $\begin{array}{c}\text { control } \\
(\mathrm{n}=32)\end{array}$ & $\begin{array}{l}\text { first experimental } \\
\quad(\mathrm{n}=40) \\
\text { coagulator }+ \text { non- } \\
\text { steroidal anti- } \\
\text { inflammatory drugs }\end{array}$ & $\begin{array}{l}\text { second experimental } \\
(\mathrm{n}=40) \\
\text { coagulator }+ \text { low } \\
\text { molecular weight } \\
\text { heparins }\end{array}$ \\
\hline Clinically healthy & \multicolumn{3}{|c|}{$1.43 \pm 0.05$} \\
\hline \multicolumn{4}{|c|}{ Benign tumours } \\
\hline Before surgery & & $1.72 \pm 0.21^{*}$ & \\
\hline 3 & $1.28 \pm 0.11$ & $2.16 \pm 0.52 *_{\bullet}$ & $2.24 \pm 0.34 * \bullet$ \\
\hline 7 & $1.37 \pm 0.05$ & $1.97 \pm 0.36 * \bullet$ & $2.05 \pm 0.49 *$ \\
\hline 10 & $1.39 \pm 0.04$ & $1.63 \pm 0.21$ & $1.65 \pm 0.22$ \\
\hline 14 & $1.42 \pm 0.06$ & $1.20 \pm 0.34$ & $1.41 \pm 0.15$ \\
\hline \multicolumn{4}{|c|}{ Malignant neoplasms } \\
\hline Before surgery & & $2.25 \pm 0.07^{* *}$ & \\
\hline 3 & $1.24 \pm 0.02 * *$ & $2.14 \pm 0.37 * \bullet$ & $2.84 \pm 0.67$ *• $^{\circ}$ \\
\hline 7 & $1.27 \pm 0.05^{*}$ & $1.98 \pm 0.19 * * . \bullet$ & $2.43 \pm 0.45 *$ \\
\hline 10 & $1.19 \pm 0.04^{*}$ & $1.52 \pm 0.21 \bullet$ & $2.06 \pm 0.38 * \bullet$ \\
\hline 14 & $1.36 \pm 0.05$ & $1.33 \pm 0.12$ & $1.98 \pm 0.46 \bullet$ \\
\hline
\end{tabular}

Note: see Table 3.

Also, we should mention a statistically significant difference between the parameters of the experimental groups and control: on the third and seventh day $(\mathrm{P}<0.05)$ among the dogs with benign tumours, and on the $3-10$ th day $(\mathrm{P}<0.05)$ in cases of malignant tumours, and also on the 14th day $(\mathrm{P}<0.05)$ in cases of using low molecular weight heparin.

The function of inhibiting the invasion and metastasis of tumours by limiting the activity of proteolytic enzymes is carried out by proteolytic inhibitors. Despite the manifested changes in the $\alpha 1$-proteinase inhibitor in female dogs with mammary tumours, indeed only surgical intervention using an electrocoagulant (control) resulted in its restoration to the physiological level, starting from $3 \mathrm{~d}$ day of the postoperative period (Table 9). Reduction of the intensity of proteolytic reactions in the organism as a result of removing the neoplasias, which synthesize a wide range of matrix metalloproteinases and different groups of cathepsins necessary for infiltration of tumour tissue, promotion of the invasion and metastasis, led to obtaining similar results after combining electrosurgical technique and pharmacological correction. At the same time, there was no statistically significant difference between the groups.

\section{Table 9}

Dynamics of activity of $\alpha_{1}$-inhibitor of proteinases in dogs with growths in the mammary glands $(\mu \mathrm{mol} / 1, \mathrm{x} \pm \mathrm{SD})$

\begin{tabular}{|c|c|c|c|}
\hline \multirow{3}{*}{$\begin{array}{c}\text { Period of } \\
\text { observation, day }\end{array}$} & \multicolumn{3}{|c|}{ Group } \\
\hline & $\begin{array}{l}\text { control } \\
(\mathrm{n}=32)\end{array}$ & $\begin{array}{l}\text { first experimental } \\
\qquad(\mathrm{n}=40)\end{array}$ & $\begin{array}{l}\text { second experimental } \\
(\mathrm{n}=40)\end{array}$ \\
\hline & coagulator & $\begin{array}{l}\text { coagulator + non- } \\
\text { steroidal anti- } \\
\text { inflammatory drugs }\end{array}$ & $\begin{array}{c}\text { coagulator }+ \text { low } \\
\text { molecular weight } \\
\text { heparins }\end{array}$ \\
\hline Clinically healthy & & $78.62 \pm 1.93$ & \\
\hline \multicolumn{4}{|c|}{ Benign tumours } \\
\hline Before surgery & & $89.80 \pm 7.53 *$ & \\
\hline 3 & $75.08 \pm 6.15$ & $82.16 \pm 5.48$ & $83.81 \pm 5.62$ \\
\hline 7 & $79.22 \pm 7.26$ & $83.09 \pm 7.14$ & $80.94 \pm 6.23$ \\
\hline 10 & $88.09 \pm 4.21$ & $87.27 \pm 7.53$ & $84.51 \pm 4.64$ \\
\hline 14 & $85.38 \pm 4.53$ & $81.11 \pm 5.61$ & $86.62 \pm 4.77$ \\
\hline \multicolumn{4}{|c|}{ Malignant neoplasms } \\
\hline Before surgery & & $105.89 \pm 8.19^{* *}$ & \\
\hline 3 & $80.35 \pm 4.19$ & $77.35 \pm 4.92$ & $80.43 \pm 2.70$ \\
\hline 7 & $71.02 \pm 6.55$ & $84.19 \pm 7.68$ & $81.26 \pm 9.12$ \\
\hline 10 & $79.82 \pm 6.17$ & $76.16 \pm 5.86$ & $84.33 \pm 6.98$ \\
\hline 14 & $82.91 \pm 4.83$ & $83.40 \pm 7.27$ & $83.23 \pm 5.08$ \\
\hline
\end{tabular}

Note: see Table 3.

During the study of the level of oxidative stress, which is an integral part of the neoplasia process, in cases of using different approaches to the treatment of this pathology, it was determined that the best results were 
obtained after using a combination operative-conservative course which included excision of neoplasms followed by prescription of a pharmacological correction (Table 10).

\section{Table 10}

Level of accumulation of malondialdehyde in patients after removal of mammary tumour $(\mu \mathrm{mol} / \mathrm{l}, \mathrm{x} \pm \mathrm{SD})$

\begin{tabular}{|c|c|c|c|}
\hline \multirow[b]{2}{*}{$\begin{array}{c}\text { Period of } \\
\text { observation, day }\end{array}$} & \multicolumn{3}{|c|}{ Group } \\
\hline & $\begin{array}{l}\text { control } \\
(\mathrm{n}=32)\end{array}$ & $\begin{array}{l}\text { first experimental } \\
\qquad(\mathrm{n}=40) \\
\text { coagulator }+ \text { non- } \\
\text { steroidal anti- } \\
\text { inflammatory drugs }\end{array}$ & $\begin{array}{c}\text { second experimental } \\
(\mathrm{n}=40) \\
\text { coagulator }+ \text { low } \\
\text { molecular weight } \\
\text { heparins }\end{array}$ \\
\hline Clinically healthy & & $9.8 \pm 0.4$ & \\
\hline \multicolumn{4}{|c|}{ Benign tumours } \\
\hline Before surgery & & $14.5 \pm 0.5^{* *}$ & \\
\hline 3 & $16.4 \pm 0.3^{* * *}$ & $17.2 \pm 0.2 * * *$ & $15.9 \pm 0.4 * * *$ \\
\hline 7 & $15.1 \pm 0.2 * *$ & $12.4 \pm 0.3^{* * \bullet \bullet}$ & $13.6 \pm 0.3 * *$ \\
\hline 10 & $12.2 \pm 0.3 * *$ & $10.6 \pm 0.2 \bullet \bullet$ & $12.4 \pm 0.3^{*}$ \\
\hline 14 & $9.3 \pm 0.5$ & $11.2 \pm 0.4$ & $9.9 \pm 0.5$ \\
\hline \multicolumn{4}{|c|}{ Malignant neoplasms } \\
\hline Before surgery & & $21.0 \pm 0.7^{* * *}$ & \\
\hline 3 & $23.5 \pm 0.6^{* * *}$ & $23.6 \pm 0.5 * * *$ & $24.6 \pm 0.4 * * *$ \\
\hline 7 & $17.1 \pm 0.5^{* * *}$ & $19.8 \pm 0.2 * * *$. & $21.2 \pm 0.6 * * * \bullet$ \\
\hline 10 & $13.0 \pm 0.3 * *$ & $15.1 \pm 0.4 * *_{\bullet \bullet}$ & $14.7 \pm 0.3 * * .$. \\
\hline 14 & $12.1 \pm 0.3^{* *}$ & $10.8 \pm 0.3 \bullet \bullet \bullet$ & $10.5 \pm 0.2 \bullet \bullet$ \\
\hline
\end{tabular}

Note: see Table 3.

Prescribing nonsteroidal anti-inflammatory agents led to normalization of the mechanisms of peroxidation of lipids in benign tumours on the 10th day of monitoring, and on the 14th day in malignant tumours. Using low molecular weight heparins caused the normalization of the level of malondialdehyde in blood on the 14th day irrespective of the pathomorphological type of neoplasm.

At the same time, the control dogs with benign neoplasms had the stabilization of the content of the products of lipid peroxidation on the 14th day in cases of their excessive accumulation in the blood (30\%) in malignant neoplasia $(\mathrm{P}<0.01)$. It should be mentioned that in malignant neoplasms, the content of malondialdehyde in the patients of the experimental groups was significantly different compared to the control animals on the 7th $(\mathrm{P}<0.01), 10$ th $(\mathrm{P}<0.01)$ and 14 th $(\mathrm{P}<0.001)$ days of the postoperative period.

The dynamics of the malonic aldehyde content in the cases of mammary tumours among female dogs is a marker of the activation of lipid peroxidation, and development of endogenous intoxication which accompanies carcinogenesis. Pharmacological correction of the hemostasis system, which regulates the intensity of the formation of free radicals, excessive accumulation of which negatively affects the cells, led to a decrease in their concentration and, therefore, damage to the tissues.

Nitrogen oxide, which participates in the regulation of inflammation and regeneration of the tissues, has a positive value for organisms suffering the neoplasia process. Its impact causes vasodilation, which increases the permeability and forms tissue swelling with the subsequent development of inflammatory reaction.

The study on the saturation of the blood with nitrogen oxide in animals with mammary tumours (Table 11) allowed us to draw a conclusion that its level in the patients of all groups with benign neoplasms varied at the level of clinically healthy dogs throughout the monitoring. In malignant neoplasms of the control animals, the restoration of the nitrogen oxide content was observed on the 14th day; in the earlier period, there was observed its excessive accumulation $(\mathrm{P}<0.05)$. Conducting corrective therapy was followed by the normalization of the level of nitric oxide in the blood after using nonsteroidal anti-inflammatory and low molecular weight heparins, starting from the three day after the neoplasia was removed.

The stability of the homeostasis in the organism is to a great extent caused by nitrogen oxide, which is the main regulator of the intra- and intercellular processes related to free radical oxidation. Thus, considering that the tumour process is accompanied by clearly manifested inflammatory reaction, we can assume the positive role of the combined method of treating mammary tumours, which includes electro-surgical removal of tumours and postoperative pharmacological correction of the hemostasis system.

\section{Table 11}

Dependence of the content of nitrogen oxide on the treatment course of femaledogs with neoplasias of mammary gland $(\mu \mathrm{mol} / \mathrm{L}, \mathrm{x} \pm \mathrm{SD})$

\begin{tabular}{|c|c|c|c|}
\hline \multirow{3}{*}{$\begin{array}{c}\text { Period of } \\
\text { observation, day }\end{array}$} & \multicolumn{3}{|c|}{ Group } \\
\hline & $\begin{array}{l}\text { control } \\
(\mathrm{n}=32)\end{array}$ & $\begin{array}{l}\text { first experimental } \\
(\mathrm{n}=40)\end{array}$ & $\begin{array}{c}\text { second experimental } \\
(\mathrm{n}=40)\end{array}$ \\
\hline & coagulator & $\begin{array}{l}\text { coagulator + non- } \\
\text { steroidal anti- } \\
\text { inflammatory drugs }\end{array}$ & $\begin{array}{c}\text { coagulator + low } \\
\text { molecular weight } \\
\text { heparins }\end{array}$ \\
\hline Clinically healthy & \multicolumn{3}{|c|}{$32.19 \pm 1.82$} \\
\hline \multicolumn{4}{|c|}{ Benign tumours } \\
\hline Before surgery & & $29.74 \pm 4.03$ & \\
\hline 3 & $33.35 \pm 2.98$ & $32.69 \pm 3.71$ & $34.37 \pm 2.50$ \\
\hline 7 & $28.39 \pm 2.33$ & $29.83 \pm 3.95$ & $31.20 \pm 2.45$ \\
\hline 10 & $29.42 \pm 2.54$ & $30.57 \pm 4.13$ & $30.61 \pm 3.58$ \\
\hline 14 & $30.07 \pm 2.98$ & $29.21 \pm 2.76$ & $28.15 \pm 2.57$ \\
\hline \multicolumn{4}{|c|}{ Malignant neoplasms } \\
\hline Before surgery & & $42.85 \pm 4.89^{*}$ & \\
\hline 3 & $38.36 \pm 3.19^{*}$ & $35.77 \pm 2.64$ & $34.96 \pm 0.85$ \\
\hline 7 & $37.78 \pm 2.47 *$ & $32.19 \pm 1.91$ & $33.56 \pm 2.48$ \\
\hline 10 & $36.08 \pm 1.13^{*}$ & $31.20 \pm 4.51$ & $32.18 \pm 3.09$ \\
\hline 14 & $34.11 \pm 1.74$ & $29.34 \pm 1.24$ & $30.46 \pm 4.55$ \\
\hline
\end{tabular}

Note: see Table 3.

The corrective effect of the proposed treatment protocols was demonstrated by a positive effect on the hemostatic status, thereby confirming its normalizing effect on the processes of lipid peroxidation after the removal of mammary tumours in dogs. Reducing the endogenous intoxication leads to optimization of the reparative regeneration processes in the postoperative period and minimizes the possibility of further development and spread of tumour cells in the body. The body's reproductive capacity reflects the content of protein molecules and their fractions in the blood. It should be mentioned that according to the reference data, the physiological concentration of total protein in dogs is 50-70 g/l. We determined that in clinically healthy females, it equals $63.07 \pm 3.21 \mathrm{~g} / \mathrm{l}$. This indicator was a starting point for further research.

The level of total protein in the previous studies in the preoperative period had significant differences between the groups of patients with malignant and benign tumours of the mammary gland by $25 \%$ (Table 12 ). That is, according to the results, the development of mammary tumours was followed by decrease in the content of total protein, which was observed more clearly in patients with malignant lesions.

\section{Table 12}

Dynamics of the total protein content in dogs with mammary tumours $(\mathrm{g} / \mathrm{l}, \mathrm{x} \pm \mathrm{SD})$

\begin{tabular}{|c|c|c|c|}
\hline \multirow{3}{*}{$\begin{array}{c}\text { Period of } \\
\text { observation, day }\end{array}$} & \multicolumn{3}{|c|}{ Group } \\
\hline & $\begin{array}{l}\text { control } \\
(\mathrm{n}=32)\end{array}$ & $\begin{array}{l}\text { first experimental } \\
(\mathrm{n}=40)\end{array}$ & $\begin{array}{l}\text { second experimental } \\
(\mathrm{n}=40)\end{array}$ \\
\hline & coagulator & $\begin{array}{l}\text { coagulator + non- } \\
\text { steroidal anti- } \\
\text { inflammatory drugs }\end{array}$ & $\begin{array}{c}\text { coagulator }+ \text { low } \\
\text { molecular weight } \\
\text { heparins }\end{array}$ \\
\hline Clinically healthy & & $63.07 \pm 3.21$ & \\
\hline \multicolumn{4}{|c|}{ Benign tumours } \\
\hline Before surgery & & $44.19 \pm 4.37 * *$ & \\
\hline 3 & $42.77 \pm 2.25 * * *$ & $51.07 \pm 1.76^{* * \bullet \bullet}$ & $55.29 \pm 5.62 \bullet$ \\
\hline 7 & $45.63 \pm 3.56^{* *}$ & $53.28 \pm 3.59^{*}$ & $57.16 \pm 3.12 \bullet$ \\
\hline 10 & $45.86 \pm 3.58 * *$ & $55.67 \pm 4.35 \bullet$ & $54.39 \pm 4.98$ \\
\hline 14 & $52.74 \pm 6.24$ & $57.78 \pm 5.14$ & $55.54 \pm 6.08$ \\
\hline \multicolumn{4}{|c|}{ Malignant neoplasms } \\
\hline Before surgery & & $54.89 \pm 2.64^{*}$ & \\
\hline 3 & $38.39 \pm 2.09^{* * *}$ & $51.96 \pm 5.74^{*} \bullet$ & $57.03 \pm 4.77 \bullet \bullet$ \\
\hline 7 & $40.43 \pm 5.01 * *$ & $54.25 \pm 4.86^{*} \bullet$ & $56.61 \pm 3.92 \bullet$ \\
\hline 10 & $46.56 \pm 4.13^{* *}$ & $58.10 \pm 3.15 \bullet$ & $54.68 \pm 4.35$ \\
\hline 14 & $45.88 \pm 4.47 * *$ & $57.43 \pm 4.77 \bullet$ & $54.13 \pm 5.25$ \\
\hline
\end{tabular}

Note: see Table 3.

Extirpation of neoplasia was followed by changes in the content of total protein, which were characterized by its gradual increase. At the same time, on the 14th day of the monitoring, in the dogs of the control 
group, restoration of the physiological parameters was observed only in cases of benign lesions. In patients of the experimental groups the total protein concentration was observed to normalize starting from the 10th day of the postoperative period with use of nonsteroidal anti-inflammatory preparations and from the $3 \mathrm{~d}$ day in cases of using low molecular weight heparins. Unlike animals of the control group, in the blood of which during 10 days after the surgical removal of benign tumours of the mammary gland a low content of total protein was recorded (by $30 \%$ ), the state of hypoproteinemia lasted the first 7 days of postoperative treatment with nonsteroidal anti-inflammatory drugs, and the use of low molecular weight heparins removed the changes in the protein metabolism on the $3 \mathrm{~d}$ day.

Extirpation of malignant tumours using the electrosurgical method did not significantly affect the content of total protein in patients: throughout the monitoring, its level remained stably low (by 30-40\%) compared to the clinically healthy dogs. Prescribing corrective therapy with nonsteroidal anti-inflammatory preparations allowed normalization of the content of total protein in 10 days, and immediately after the surgery after using low molecular weight heparin. Thus, we can assume that the proposed protocols of pharmacological correction of the hemostasis system optimize regenerative processes in the organism reducing the recovery period.

The main proteins that provide transportation of hydrophobic metabolites in the circulatory system of the organism, particularly cellular metabolism products, mediators and other compounds, the total amount of which reflects the pattern and intensity of the physiological and pathological processes in the body, are albumins. The obtained results indicate that there are no disorders in the level of albumin both in the preoperative period and after the surgery: it ranged within the limits of physiological parameters in all groups of animals in the absence of a significant difference between them (Table 13). Only on the 14th day, were the animals of the control group recorded to have a insignificant decrease to $24.05 \pm 2.76 \mathrm{~g} / 1(\mathrm{P}<0.05)$, which is probably related to the complicated process of reparative regeneration of surgical wounds. Albumin belongs to the negative proteins of the acute phase of inflammation. Considering that they are highly hydrophilic and bind a large amount of water, one can predict that in cases of tumours, an increase in the coagulation processes occurs due to the disorders of hemostasis mechanisms, and is not related to dehydration.

Table 13

Albumin concentration in patients

with mammary neoplasia $(\mathrm{g} / \mathrm{l}, \mathrm{x} \pm \mathrm{SD})$

\begin{tabular}{|c|c|c|c|}
\hline \multirow[b]{2}{*}{$\begin{array}{c}\text { Period of } \\
\text { observation, day }\end{array}$} & \multicolumn{3}{|c|}{ Group } \\
\hline & $\begin{array}{c}\text { control } \\
(\mathrm{n}=32)\end{array}$ & $\begin{array}{l}\text { first experimental } \\
\qquad(\mathrm{n}=40) \\
\text { coagulator }+ \text { non- } \\
\text { steroidal anti- } \\
\text { inflammatory drugs }\end{array}$ & $\begin{array}{l}\text { second experimental } \\
\qquad(\mathrm{n}=40) \\
\text { coagulator }+ \text { low } \\
\text { molecular weight } \\
\text { heparins }\end{array}$ \\
\hline Clinically healthy & & $31.17 \pm 2.23$ & \\
\hline \multicolumn{4}{|c|}{ Benign tumours } \\
\hline Before surgery & & $29.25 \pm 5.81$ & \\
\hline 3 & $27.73 \pm 2.53$ & $27.84 \pm 5.57$ & $25.87 \pm 1.50 *$ \\
\hline 7 & $27.14 \pm 4.05$ & $26.84 \pm 4.71$ & $27.23 \pm 2.61$ \\
\hline 10 & $26.28 \pm 3.75$ & $28.94 \pm 5.15$ & $28.03 \pm 3.18$ \\
\hline 14 & $24.05 \pm 2.76^{*}$ & $29.28 \pm 6.04$ & $27.84 \pm 5.67$ \\
\hline \multicolumn{4}{|c|}{ Malignant neoplasms } \\
\hline Before surgery & & $30.53 \pm 4.88$ & \\
\hline 3 & $32.17 \pm 4.22$ & $34.70 \pm 1.87$ & $31.86 \pm 2.98$ \\
\hline 7 & $31.53 \pm 4.19$ & $33.65 \pm 4.91$ & $31.08 \pm 2.77$ \\
\hline 10 & $29.79 \pm 3.62$ & $31.51 \pm 3.21$ & $29.52 \pm 3.46$ \\
\hline 14 & $30.23 \pm 2.11$ & $34.01 \pm 3.77$ & $29.78 \pm 2.95$ \\
\hline
\end{tabular}

Note: see Table 3.

The determination of ceruloplasmin, one of the mediators which regulate the activity of proteolytic enzymes in the presence of inflammatory reaction in the tumour for assessing the intensity of the inhibitory system, shows (Table 14) that in the dogs with benign tumours of the mammary gland it decreased on average by $15 \%$ in the absence of changes in the patients with malignant tumours in the conditions of significant difference in its levels, depending on the pathomorphological type of neoplasms.

\section{Table 14}

Concentration of ceruloplasmin in dogs with tumours of the mammary glands in relation to the treatment method $(\mathrm{mg} / \mathrm{l}, \mathrm{x} \pm \mathrm{SD})$

\begin{tabular}{|c|c|c|c|}
\hline \multirow[b]{2}{*}{$\begin{array}{c}\text { Period of } \\
\text { observation, day }\end{array}$} & \multicolumn{3}{|c|}{ Group } \\
\hline & $\begin{array}{l}\text { control } \\
(\mathrm{n}=32)\end{array}$ & $\begin{array}{l}\text { experimental first } \\
\quad(\mathrm{n}=40) \\
\text { coagulator + non- } \\
\text { steroidal anti- } \\
\text { inflammatory drugs }\end{array}$ & $\begin{array}{l}\text { experimental second } \\
\qquad(\mathrm{n}=40) \\
\text { coagulator }+ \text { low } \\
\text { molecular weight } \\
\text { heparins }\end{array}$ \\
\hline Clinically healthy & & $28.77 \pm 0.34$ & \\
\hline \multicolumn{4}{|c|}{ Benign tumours } \\
\hline Before surgery & & $24.74 \pm 0.36^{* * *}$ & \\
\hline 3 & $39.37 \pm 3.45^{* *}$ & $37.94 \pm 3.27 * *$ & $35.86 \pm 1.54 * *$ \\
\hline 7 & $35.89 \pm 3.31 * *$ & $34.11 \pm 2.34^{*}$ & $33.61 \pm 4.17^{*}$ \\
\hline 10 & $35.63 \pm 2.47 * *$ & $28.47 \pm 3.19 \bullet$ & $32.31 \pm 2.27^{*}$ \\
\hline 14 & $31.08 \pm 3.46$ & $26.20 \pm 2.47$ & $27.67 \pm 2.34$ \\
\hline \multicolumn{4}{|c|}{ Malignant neoplasms } \\
\hline Before surgery & & $28.31 \pm 0.42$ & \\
\hline 3 & $43.27 \pm 1.87 * * *$ & $38.35 \pm 2.68^{* *}$ & $44.10 \pm 5.57 * * *$ \\
\hline 7 & $41.48 \pm 3.39^{* *}$ & $37.11 \pm 4.26^{*}$ & $39.43 \pm 4.84^{*}$ \\
\hline 10 & $37.94 \pm 4.26^{*}$ & $32.18 \pm 3.47$ & $34.22 \pm 2.86^{*}$ \\
\hline 14 & $36.27 \pm 3.58^{*}$ & $26.33 \pm 4.85$ & $31.20 \pm 3.44$ \\
\hline
\end{tabular}

Note: see Table 3 .

The postoperative period for benign neoplasms is characterized by accumulation of ceruloplasmin during 7 days in the first experimental group, 10 days in the control and second experimental groups. The patients with malignant neoplasias had excessive accumulation of this marker in the control groups during 14 days, 7 days - in cases of using nonsteroidal anti-inflammatory preparations, 10 days in cases of using low molecular weight heparins, which is related to its main function as an osteopathic protein - the protection of biological membranes by inhibition of proteolytic cascade systems, complement, coagulation and fibrinolysis in conditions of inflammation.

The presented results indicate the effectiveness of using corrective courses after the extirpation of mammary tumours of dogs. Conducting pharmacological correction after excision of the tumour resulted in the normalization of the content of ceruloplasmin in cases of prescribing nonsteroidal anti-inflammatory agents on the 10th day, and on the 14th day in cases of using low molecular weight heparins. The obtained results suggest that the use of pharmacological correction of hemostasis status recovers the balance of proteins due to their rational use, reducing the intensity of reactions in which they take part directly or indirectly, except for inflammation, normalizes the ratio of synthesis/disintegration, initiates increase in the production of immunoproteins.

Summarizing the data obtained during the study of the effects of nonsteroidal anti-inflammatory and low molecular weight heparins on the system of hemostasis in dogs that had been operated on for breast tumours, we can state the following. The markers indicated deep disorders of the hemostasis balance during the postoperative period in the patients in cases of using the electrosurgical method of extirpation of tumours. Optimization of the processes of reparative regeneration is possible during the course of corrective therapy which is based on nonsteroidal anti-inflammatory drugs or low molecular weight heparins. Restoration of hemostasis equilibrium in such animals indicates a higher intensity of regenerative processes compared to alteration.

The presented results allow us to supplement the methodological basis of veterinary medicine with new effective protocols which improve the efficiency of treating mammary tumours of dogs and form a basis for further research orientated to development of alternative methods of preventing relapses and metastasis.

\section{Discussion}

Currently, despite the wide distribution of mammary tumours among small domestic animals, there is no united information base for cancer patients, which would include the data on patients, description of general and pathological changes, treatment protocols and the results of their use. At the same time (Talahadze et al., 2012), there is no general methodological approach to the verification of tumours, and Owen's histological classification for animals (1980) is insufficient to cover the 
pathogenesis of neoplasms and therefore requires a correction based on the latest studies on the mechanisms of development of this pathology. Clinical TNM classification requires taking into account the immunohistochemical profile of tumours, molecular genetic characteristics, which would allow us to not only make a more accurate prognosis of the course of the disease, but also recommend optimal treatment tactics (Ferreira et al., 2011; Losiewicz et al., 2014). The research conducted confirms the widespread distribution of tumour lesions of the mammary gland, which is also typical for other regions (Dhami et al., 2010; Mysak, 2010; Glazunova et al., 2014).

The study of the pathogenesis is characterized by low activity of scientists in this area and a similarity in their studies (Mischke et al., 2005). In most cases, one or several indicators are being determined, which only reflect the orientation of changes in the coagulation and proteolytic mechanisms, but do not reveal the nature of the changes (Vilar Saavedra et al., 2011). The diseases, treatment of which requires the study of hemostatic status as an important element of the pathogenesis, are, first of all, tumours.

An important role in the carcinogenesis of the mammary gland is played by inflammation which causes release of signaling molecules (cyclooxygenase-2, tumour epidermal growth factor, angiogenic vascular endothelial growth factor, other proangiogenic factors, chemokines, cytokines) which exacerbate the inflammation and contribute to survival, reproduction and spread of the tumour cells (Pinho et al., 2012).

The information given above confirms the presence of disorders in the coagulation system in dogs with mammary tumours, characterized by high probability of bleeding in cases of malignant course (prolongation of activated partial thromboplastin time in $50 \%$ of patients) due to consumption coagulopathy; in cases of benign tumours there is significant risk of thrombosis (it decreased in $71.4 \%$ of the animals).

The activation of the proteolytic systems, particularly the fibrinolytic, plays an important part in the invasion of the malignant cells and the development of metastases, the mechanisms of which involve several classes of proteases, first of all the plasminogen activation proteolytic cascade with the formation of a plasmin that activates the matrix metalloproteases which destroy collagen and other components of the tumour stroma (Corte et al., 2005; Salman et al., 2009; Jessen et al., 2010).

The average level of the inhibitors of proteolysis indicates an increase in their activity in neoplasms. It was significantly higher in cases of malignant neoplasms compared to benign neoplasms. The obtained data indicate that the development of neoplasms in the mammary gland of dogs in most cases is accompanied by excessive activation of the $\alpha_{1}$ proteinase inhibitor and $\alpha_{2}$-macroglubulin. The abovementioned changes in the content of acute-phase proteins, which follow the suppression of fibrinolytic activity characterize the organism's attempts to eliminate the threat of thrombosis and localize the inflammatory process which accompany the development of neoplasms.

Our previous studies (Rublenko \& Bilyj, 2012) indicate significant disorders in the hemostatic status of bitches with mammary tumours, in particular the presence of oxidative stress in cases of malignant lesions (Rublenko \& Bilyj, 2014), justifying the usefulness of its pharmacological correction in the postoperative period, and also the advantage of an electrosurgical technique over the generally accepted one.

The results obtained on the possibility of restoring the hemostasis status in animals with mammary tumours by their removal followed by prescription of the correcting protocols, are confirmed by the studies conducted in human medicine (Masljakova et al., 2017), according to which the disorders in the mechanisms of coagulation in tumours has a reverse pattern. A promising direction for further research is the use of nonsteroidal anti-inflammatory agents for the prevention of mammary tumours of dogs: this is indicated by the results of the monitoring conducted in human medicine (Harris et al., 2003).

The results of clinical testing of non-steroidal anti-inflammatory agents in dogs with cancer confirm the conclusions (Tran-Thanh et al., 2010) about the ability to prevent the growth of mammary tumours using a selective inhibitor of cyclooxygenase- 2 . The conclusions are based on research in which the animals were used as biological models, although information on the use of nonselective agents of this pharmacological group is controversial.
At the same time, in human medicine, the use of nonsteroidal antiinflammatory preparations and low molecular weight heparins was justified (Koh et al., 2013; Hevia et al., 2017), and in veterinary oncology, this correction is not used. Only roncoleukin monotherapy was proposed (Korobova, 2005), but the efficacy was determined using only the clinical criteria, which does not allow one to make an objective prognosis of the course of the disease. That is, the problem of postoperative treatment of animals with cancer is not solved, hence the necessity of studies orientated to the development and clinical implementation of pathogenetically justified courses of pharmacological correction of hemostasis for such patients and the criteria for their evaluation.

The positive effect of the proposed protocol for breast cancer in female dogs can be explained by its influence on the main element of carcinogenesis, which was proved by the study of the effects of the immunostimulants, hemostatic preparations, nonsteroidal anti-inflammatory drugs and low molecular weight heparins on the development of neoplasms in human medicine.

The main direction of the pharmacological influence on the neoplasia process is the stimulation of the immune response of the organism, in particular the direct and indirect effects on the immune-competent cells (Hegmans \& Aerts, 2014). In the proposed protocol, the antitumour activity was induced by roncoleukin, which directly damages the tumour cells, and significantly stimulates the local immune reaction and activates the immune defense organs, and also indirectly affects the carcinogenesis by activating different cells of the immune system (Zlatnik et al., 2012).

The use of nonsteroidal anti-inflammatory agents has been shown to reduce the inflammatory process caused by tumours as well as surgical intervention. This coincides with its proven anti-inflammatory, analgesic and antipyretic action (Brown et al., 2001). Some researchers (Hussain et al., 2012) described their immunomodulatory effects related to the influence on the immune cells, and also to macrophages, dendritic, T-effector and regulatory $\mathrm{T}$ cells related to the growths.

The results obtained confirm the antitumour effect of nonsteroidal anti-inflammatory preparations, which, perhaps, occur as a result of strengthening of apoptosis, as was determined in a study using cellular lines of tumours in dogs (Wilson et al., 2012). Considering the similarity of the development of tumours in human and dogs, it can be assumed that the prophylactic effect of non-steroidal anti inflammatory preparations on the development of neoplasms is related to decrease in the level of estradiol (Horn et al., 2010), presence of HER2 gene and the receptors in the tumour cells (Dierssen-Sotos et al., 2016).

The results obtained coincide with the data presented in human medicine (Marchetti et al., 2008; Promzeleva et al., 2012) on the efficiency of using low molecular weight heparins against growths in the mammary gland in the postoperative period. In this case, the inhibition of the development and distribution of tumours is explained by the activation of apoptosis of neoplastic cells and inhibition of the expression of the vascular endothelial growth factor (Yin et al., 2014), by inflammation through NFkappaB, the main enzymes which negatively affect the matrix, platelet and adherence cell interaction, and the effect on the release of the tissue pathway inhibitor factor, inhibition of selective modulation (Mousa, 2010; Heyman \& Yang, 2016).

Despite discussion on the use of nonsteroidal anti-inflammatory preparations and low molecular weight heparins, on the basis of the pathogenesis of breast cancer and the results obtained, it can be stated that they have been proven to be efficient in case of this pathology.

In our opinion, the proposed therapeutic direction for breast tumours has certain advantages over the generally accepted protocols. The courses we recommend, which affect the key pathogenetic mechanisms of the neoplastic process, create unfavourable conditions for tumour transformation, activate and enhance antitumour protection without causing toxic effects on the organism. At the same time, selecting preparations for pharmacological correction is carried out in accordance with the peculiarities of hemostasic changes in a particular patient, and not by the pathomorphological type of a tumour, which permits an individual approach to blocking the key pathogenetic mechanisms of the neoplastic transformation. 


\section{Conclusions}

High coagulation potential for breast tumours in female dogs causes an increased risk of vascular thrombosis and promotes dissemination of the neoplastic cells. The presence of prolonged postoperative coagulopathy proves the need for a pharmacological correction aimed at restoring the hemostasis equilibrium, which is an important factor for improving the long-term prognosis for patients with cancer.

Using the protocol of pharmacological correction of the hemostasis system (roncoleukin, trannexam and acelysin or phenox) after electrosurgical removal of mammary tumours of female dogs facilitates normalization of the hemostasis mechanisms within 14 days of surgery, thus reducing the risk of thrombosis and the probability of relapse and metastasis. The proven efficiency of the combined method of treating dogs with the mammary tumours, which includes electrocoagulation of tumours and the pharmacological correction of the hemostasis status, allows us to recommend it for broad introduction into clinical veterinary practice.

\section{References}

Andreeva, L. I., Kozhemjakin, L. A., \& Kishkun, A. A. (1988). Modifikacija metoda opredelenija perekisej lipidov $\mathrm{v}$ teste s tiobarbiturovoj kislotoj [Modification of the method for determination of lipid peroxides in the test with thiobarbituric acid]. Laboratornoe Delo, 11, 41-43 (in Russian).

Abdullah, M. A., Almufty, B. I., Yasin, M. I., \& Hassan, N. J. (2014). Clinical and histopathological study of mammary tumors in foreing dogs breeds in Kurdistan region of Iraq. Basrah Journal of Veterinary Research, 1(1), 11-19.

Astrup, T., \& Mullertz, S. (1952). The fibrin plate metod for estimating fibrinolitic activity. Archives of Biochemistry and Biophysics, 40, 346-351.

Beha, G., Brunetti, B., Asproni, P., Muscatello, L., Millanta, F., Poli, A., Sarli, G., \& Benazzi, C. (2012). Molecular portrait-based correlation between primary canine mammary tumor and its lymph node metastasis: Possible prognosticpredictive models and/or stronghold for specific treatments? Biomed Central Veterinary Research, 8, 219-228.

Belicer, V. O., Varecka, T. V., \& Veremjejenko, K. M. (1997). Kil'kisne vyznachennja fibrynogenu v plazmi krovi ljudyny [Quantitative determination of fibrinogen in human plasma]. Laboratoma Diagnostyka, 2, 53-55 (in Ukrainian).

Boccaccio, C., \& Medico, E. (2006). Cancer and blood coagulation. Cellular and Molecular Life Sciences, 63(9), 1024-1027.

Bonnett, B. N., Egenvall, A., Hedhammar, A., \& Olson, P. (2005). Mortality in over 350,000 insured Swedish dogs from 1995-2000: I. Breed-, gender-, age- and cause-specific rates. Acta Veterinaria Scandinavica, 46(3), 105-120.

Brønden, L. B., Flagstad, A., \& Kristensen, A. T. (2007). Veterinary cancer Registries in companion animal cancer: A review. Veterinary and Comparative Oncology, 5(3), 133-144.

Brown, W. A., Skinner, S. A., Malcontenti-Wilson, C., Vogiagis, D., \& O'Brien, P. E. (2001). Non-steroidal anti-inflammatory drugs with activity against either cyclooxygenase 1 or cyclooxygenase 2 inhibit colorectal cancer in a DMH rodent model by inducing apoptosis and inhibiting cell proliferation. British Medical Journal, 48, 660-666.

Corte, M. D., Vérez, P., Rodríguez, J. C., Roibás, A., Domínguez, M. L., Lamelas, M. L., Vázquez, J., García Muñiz, J. L., Allende, M. T., González, L. O., Fueyo, A., \& Vizoso, F. (2005). Tissue-type plasminogen activator (tPA) in breast cancer: Relationship with clinicopathological parameters and prognostic significance. Breast Cancer Research, 90(1), 33-40.

Dhami, M. A., Tank, P. H., Karle, A. S., Vedpathak, H. S., \& Bhatia, A. S. (2010). Epidemiology of canine mammary gland tumours in Gujarat. Veterinary World, 3(6), 282-285.

Dierssen-Sotos, T., Gómez-Acebo, I., Pedro, M., Pérez-Gómez, B., Servitja, S., Moreno, V., Amiano, P., Fernandez-Villa, T., Barricarte, A., Tardon, A., Diaz-Santos, M., Peiro-Perez, R., Marcos-Gragera, R., Lope, V., GraciaLavedan, E., Alonso, M. H., Michelena-Echeveste, M. J., Garcia-Palomo, A., Guevara, M., Castaño-Vinyals, G., Aragonés, N., Kogevinas, M., Pollán, M., \& Llorca, J. (2016). Use of non-steroidal anti-inflammatory drugs and risk of breast cancer: The Spanish Multi-Case-Control (MCC) study. BioMed Central Cancer, 16, 660 .

Eierskyte, A., Zamokas, G., Grigonis, A., \& Juodiiukyniene, N. (2011). The retrospective analysis of mammary tumors in dogs. Veterinarija ir Zootechnika, $53,3-8$.

Ferreira, E., Gobbi, H., Saraiva, B. S., \& Cassali, G. D. (2011). Histological and immunohistochemical identification of atypical ductal mammary hyperplasia as a preneoplastic marker in dogs. Veterinary Pathology, 49(2), 322-329.
Fürdös, I., Fazekas, J., Singer, J., \& Jensen-Jarolim, E. (2015). Translating clinical trials from human to veterinary oncology and back. Journal of Translational Medicine, 13, 265.

Gardner, H. L., Fenger, J. M., \& London, C. A. (2016). Dogs as a model for cancer. Annual Review of Animal Biosciences Journal Impact, 4, 199-222.

Glazunova, L. A., \& Koneva, A. V. (2014). Sravnitel'naja effektivnost' razlichnyh prijomov pri lechenii novoobrazovanij molochnoj zhelezy u sobak i koshek [Comparative effectiveness of various methods in the treatment of neoplasms of the breast in dogs and cats]. Sovremennye Problemy Nauki i Obrazovanija, 6, 18-24 (in Russian).

Golikov, P. P. (2004). Oksid azota v klinike neotlozhnyh zabolevanij [Nitric oxide in the clinic for urgent diseases]. Medpraktika, Moscow (in Russian).

Grandi, F., Colodel, M. M., Monteiro, L. N., Leão, J. R., \& Rocha, N. S. (2016). Extramedullary hematopoiesis in a case of benign mixed mammary tumor in a female dog: Cytological and histopathological assessment. Biomed Central Veterinary Research, 6, 45 .

Gundim, L. F., de Araújo, C. P., Blanca, W. T., Guimarães, E. C., \& Medeiros, A. A. (2016). Clinical staging in femaleses with mammary tumors: influence of type and histological grade. Canadian Joumal of Veterinary Research, 80(4), 318-322.

Harris, R. E., Chlebowski, R. T., Jackson, R. D., Frid, D. J., Ascenseo, J. L., Anderson, G., Loar, A., Rodabough, R., White, E., \& McTiernan, A. (2003). Breast cancer and nonsteroidal anti-inflammatory drugs prospective results from the women's health initiative. Cancer Research, 63, 6096-6101.

Heading, K. L., Brockley, L. K., \& Bennett, P. F. (2011). CCNU (lomustine) toxicity in dogs: A retrospective study (2002-07). Australian Veterinary Journal, 89(4), 109-116.

Hegmans, J. P., \& Aerts, J. G. (2014). Immunomodulation in cancer. Current Opinion in Pharmacology, 17, 17-21.

Heyman, B., \& Yang, Y. (2016). Mechanisms of heparanase inhibitors in cancer therapy. Experimental Hematology, 44(11), 1002-1012.

Hevia, G., Pablos, I., Clavell, M., Raymond, J., Labrada, M., \& Fernández, L. E. (2017). Cyclooxygenase inhibition in cancer immunotherapy: Combination of indomethacin with cancer vaccines is not always beneficial. Journal of Cancer Therapy, 8, 188-209.

Horn, S. L., \& Fentiman, I. S. (2010). The role of non-steroidal anti-inflammatory drugs in the chemoprevention of breast cancer. Pharmaceuticals, 3, 1550-1560.

Hussain, M., Javeed, A., Ashraf, M., Al-Zaubai, N., Stewart, A., \& Mukhtar, M. M. (2012). Non-steroidal anti-inflammatory drugs, tumour immunity and immunotherapy. Pharmacological Research, 66(1), 7-18.

Jessen, L. R., Wiinberg, B., Kjelgaard-Hansen, M., Jensen, A. L., Rozanski, E., \& Kristensen, A. T. (2010). Thrombin-activatable fibrinolysis inhibitor activity in healthy and diseased dogs. Veterinary Clinical Pathology, 39(3), 296-301.

Khamis, Z. I., Sahab, Z. J., \& Sang, Q.-X. A. (2012). Active roles of tumor stroma in breast cancer metastasis. International Journal of Breast Cancer, 2012, 1-10.

Khanna, C., Rosenberg, M., \& Vail, D. M. (2015). A review of paclitaxel and novel formulations including those suitable for use in dogs. Journal of Veterinary Internal Medicine, 29(4), 1006-1012.

Koh, Y. W., Park, C, Yoon, D. H., Suh, C., \& Huh, J. (2013). Prognostic significance of COX-2 expression and correlation with Bcl-2 and VEGF expression, microvessel density, and clinical variables in classical Hodgkin lymphoma. The American Journal of Surgical Pathology, 37(8), 1242-1251.

Korobova, N. V. (2005). Opyt primenenija Ronkolejkina na pozdnih stadijah onkologicheskih zabolevanij molochnyh zheljoz [Experience in the use of Roncoleukin in the late stages of oncological diseases of the mammary glands]. Veterinarnaja Klinika, 34, 21 (in Russian).

Leach, T. N., Childress, M. O., Greene, S. N., Mohamed, A. S., Moore, G. E., Schrempp, D. R., Lahrman, S. R., \& Knapp, D. W. (2012). Prospective trial of metronomic chlorambucil chemotherapy in dogs with naturally occurring cancer. Veterinary and Comparative Oncology, 10(2), 102-112.

Levine, M. N., Lee, A. Y., \& Kakkar, A. K. (2005). Thrombosis and cancer. Proceedings of the Annual Meeting of the American Society for Clinical Oncology, 13-17, 748-747.

Losiewicz, K., Chmielewska-Krzesinska, M., Socha, P., Jakimiuk, A., \& Wąsowicz, K. (2014). MiRNA-21, miRNA-10b, and miRNA-34a expression in canine mammary gland neoplasms. Bulletin of the Veterinary Institute in Pulawy, 58, 447-451.

Marchetti, M., Vignoli, A., Russo, L., Balducci, D., Pagnoncelli, M., Barbui, T., \& Falanga, A. (2008). Endothelial capillary tube formation and cell proliferation induced by tumor cells are affected by low molecular weight heparins and unfractionated heparin. Thrombosis Research, 121(5), 637-645.

Marchetti, V., Giorgi, M., Fioravanti, A., Finotello, R., Citi, S., Canu, B., Orlandi, P., Desidero, T. D., Danesi, R., \& Bocci, G. (2012). First-line metronomic chemotherapy in a metastatic model of spontaneous canine tumours: A pilot study. Investigational New Drugs, 30(4), 1725-1730.

Masljakova, G. N., Fedorov, V. J., Krekova, N. J., \& Cheburkaeva, M. J. (2017). Izmenenija gemokoaguljacii pri progressirovanii raka molochnoj zhelezy [Changes in hemocoagulation in the progression of breast cancer]. Medicinskij Al'manah, 2, 151-154 (in Russian). 
Mischke, R., Fehr, M., \& Nolte, I. (2005). Efficacy of low molecular weight heparin in a canine model of thromboplastin-induced acute disseminated intravascular coagulation. Research in Veterinary Science, 79(1), 69-76.

Mousa, S. A. (2010). Heparin and low-molecular weight heparins in thrombosis and beyond. Anticoagulants, Antiplatelets, and Thrombolytics, 663, 109-132.

Mysak, A. R. (2010). Porivnjal'ni aspekty monitoryngu neoplazij u sobak [Comparative aspects of neoplasia monitoring in dogs]. Naukovyj Visnyk Veterynarnoi' Medycyny, 76(4), 75-80 (in Ukrainian).

Ostrander, E. A., \& Engl, N. (2012). Both ends of the leash - the human links to good dogs with bad genes. The New England Journal of Medicine, 367, 636-646.

Owen, L. N. (Ed.). (1980). TNM classification of tumors in domestic animals. Geneva, World Health Organization.

Pinho, S. S., Carvalho, S., Cabral, J., Reis, C. A., \& Gärtner, F. (2012). Canine tumors: A spontaneous animal model of human carcinogenesis. American Journal of Translational Research, 3, 165-172.

Promzeleva, N. V., Zorina, V. N., \& Zorin, N. A. (2012). Belki semejstva macroglobulinov pri rake molochnoj zhelezy [Proteins of the family of macroglobulins in breast cancer]. Voprosy Onkologii, 5, 688-690 (in Russian).

Rublenko, M. V., \& Bilyj, D. D. (2012). Funkcional'ni porushennja ta systemni rozlady gemostazu za novoutvoren' u sobak [Functional disorders and systemic haemostasis disorders due to neoplasms in dogs]. Naukovo-Tehnichnyj Bjuleten', 13, 142-145 (in Ukrainian).

Rublenko, M. V., \& Bilyj, D. D. (2014). Znachennja oksydantnogo stresu v patogenezi puhlyn molochnoi' zalozy u sobak [Significance of oxidative stress in the pathogenesis of breast cancer in dogs]. Problemy Zooinzhenerii' ta Veterynarnoi' Medycyny, 29(2), 75-78 (in Ukrainian).

Salman, T., Bilici, A., \& Ustaalioglu, B. O. (2009). The correlation of thrombinactivated fibrinolysis inhibitor (TAFI) levels and clinicopathologic factors in advanced colorectal cancer patients. Journal of Clinical Oncology, 27, 27-32.

Sarrau, S., Jourdan, J., Dupuis-Soyris, F., \& Verwaerde, P. (2007). Effects of postoperative ketamine infusion on pain control and feeding behaviour in femaleses undergoing mastectomy. Journal of Small Animal Practice, 48, 670-676.

Shafiee, R., Javanbakht, J., Atyabi, N., Kheradmand, P., Kheradmand, D., Bahrami, A., Daraei, H., \& Khadivar, F. (2013). Diagnosis, classification and grading of canine mammary tumours as a model to study human breast cancer: An clinico-cytohistopathological study with environmental factors influencing public health and medicine. Cancer Cell International, 13, 469.

Sorenmo, K. U., Kristiansen, V. M., Cofone, M. A., Shofer, F. S., Breen, A. M., Langeland, M., Mongil, C. M., Grondahl, A. M., Teige, J., \& Goldschmidt, M. H. (2009). Canine mammary gland tumours; A histological continuum from benign to malignant; clinical and histopathological evidence. Veterinary and Comparative Oncology, 7(3), 162-172.

Talahadze, N. T., Zurrida, S., Vorotnikov, I. G., Chhikvadze, N. V., Nechushkin, M. I., Petrovskij, A. V., Paolo, A., Dzhjermana, L., Dzhuzeppe, V., Dzhjermana, L., \& Umberto, V. (2012). Klassifikacija zlokachestvennyh opuholej molochnoj zhelezy po sisteme TNM: Neobhodimost' peremen [Classification of malignant tumors of the breast by the TNM system: The need for changes]. Vestnik RONC imeni N. N. Blohina, 23(1), 69-76 (in Russian).

Tran-Thanh, D., Buttars, S., Wen, Y., Wilson, C., \& Done S. J. (2010). Cyclooxygenase-2 inhibition for the prophylaxis and treatment of preinvasive breast cancer in a HER-2/Neu mouse model. Cancer Prevention Research, 3(2), 202-211.

Tripp, C. D., Fidel, J., Anderson, C. L., Patrick, M., Pratt, C., Sellon, R., \& Bryan, J. N. (2011). Tolerability of metronomic administration of lomustine in dogs with cancer. Journal of Veterinary Internal Medicine, 25(2), 278-284.

Vareckaja, T. V., Mihajlovskaja, L. I., \& Svital'skaja, L. A. (1992). Opredelenie rastvorimogo fibrina $v$ plazme krovi [Determination of soluble fibrin in blood plasma]. Klinicheskaja Laboratornaja Diagnostika, 7-8, 10-14 (in Russian).

Veremeenko, K. N., Volohonskaja, L. I., \& Kizim, A. I. (1978). Metody opredelenija prekallikrein-kallikreinovoj sistemy v krovi cheloveka [Methods for the determination of prekallikrein-kallikrein system in human blood]. Kyiv (in Russian).

Vilar Saavedra, P., Lara García, A., Zaldívar López, S., \& Couto, G. (2011). Hemostatic abnormalities in dogs with carcinoma: A thromboelastographic characterization of hypercoagulability. Veterinary Journal, 190(2), 78-83.

Wilson, H., Chadalapaka, G., Jutooru, I., Sheppard, S., Pfent, C., \& Safe, S. (2012). Effect of tolfenamic acid on canine cancer cell proliferation, specificity protein (sp) transcription factors, and sp-regulated proteins in canine osteosarcoma, mammary carcinoma, and melanoma cells. Journal of Veterinary Internal Medicine, 26(4), 977-986.

Yin, W., Zhang, J., Jiang, Y., \& Juan, S. (2014). Combination therapy with low molecular weight heparin and Adriamycin results in decreased breast cancer cell metastasis in $\mathrm{C}_{3} \mathrm{H}$ mice. Experimental and Therapeutic Medicine, 8(4), 1213-1218.

Zlatnik, E. A., \& Nikipelova, O. F. (2012). Regressija opuholi i lokal'nye immunenye reakcii pri razlichnyh sposobah vvedenija ronkolejkina $\mathrm{v}$ jeksperimente [Tumor regression and local immune responses in various ways of administering Roncoleukin in the experiment]. Nauchnye Vedomosti. Serija Medicina, Farmacija, 129(10), 147-151 (in Russian). 